
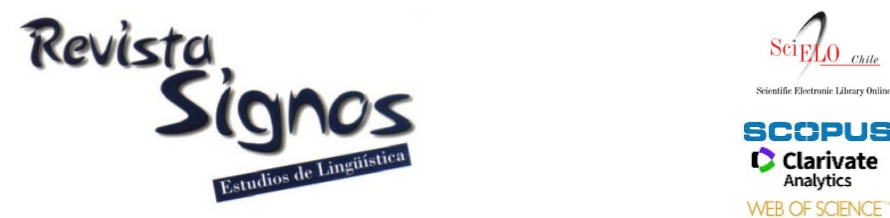

\title{
Teachers' beliefs and practices towards communicative language teaching in the expanding circle
}

\section{Creencias y prácticas de los profesores hacia la enseñanza comunicativa de las lenguas en el círculo en expansión}

\author{
Arezoo Ashoori Tootkaboni \\ ALLAMEH TABATABA'I UNIVERSITY \\ IRAN \\ a.ashoori1985@gmail.com
}

Recibido: 18-V-2017 / Aceptado: 11-VII-2018

DOI: $10.4067 /$ S0718-09342019000200265

\begin{abstract}
Although communicative approach has been adopted by many textbooks and curricula all over the world, research findings indicate that communicative language teaching (CLT) tenets in classrooms are scarce, with most teachers declaring dedication to the communicative approach but applying more traditional structural approaches in their real practice. The literature suggests that one of the reasons of the inconsistency between theory and classroom practice may be due to neglecting teachers' beliefs. In an effort to recognize teachers' beliefs towards the communicative approach within the English as a Foreign Language context of Iran, a Likert-type scale was developed and validated. The present study concentrates on the development and use of the questionnaire on a sample of 154 Iranian English language teachers whose classroom practices were also observed and evaluated for further investigations. Based on collected data, it was revealed that the majority of teachers had high levels of perception about CLT tenets. However, the study conversely showed that there is a clear mismatch between their beliefs and practical application of CLT.
\end{abstract}

Key Words: Communicative Language Teaching, teachers' beliefs, teachers' practice, questionnaire development, questionnaire validation. 


\section{Resumen}

Aunque el enfoque comunicativo ha sido adoptado por muchos libros de texto y currículos de todo el mundo, los hallazgos de la investigación indican que los principios de la enseñanza de las lenguas desde el enfoque comunicativo (EC) en las aulas son escasos, con la mayoría de los profesores declarando dedicación al enfoque comunicativo pero aplicando enfoques estructurales más tradicionales en su práctica real. La literatura sugiere que una de las razones de la inconsistencia entre la teoría y la práctica de la clase puede deberse al descuido de las creencias de los profesores. En un esfuerzo por reconocer las actitudes de los maestros hacia el enfoque comunicativo en el contexto del inglés como lengua extranjera en Irán, se desarrolló y validó una escala de actitudes tipo Likert. El presente estudio se centra en el desarrollo y uso de la escala de actitud en una muestra de 154 profesores de lengua inglesa iraní cuyas prácticas en el aula también se han observado y evaluado para futuras investigaciones. Sobre la base de los datos recabados por medio de un cuestionario y una lista de verificación de observación, los resultados generales mostraron que la mayoría de los profesores tenían altos niveles de percepción acerca de los principios EC. Sin embargo, el estudio inversamente reveló que existe un claro desajuste entre su comprensión teórica y su aplicación práctica.

Palabras Clave: Enseñanza de lenguaje comunicativo, actitudes de los maestros, práctica docente, desarrollo de cuestionarios, validación del cuestionario.

\section{INTRODUCTION}

The advent of communicative language teaching as a reaction to approaches such as structuralism and situational methods can be traced back to Hymes (1972). Owing to its focus on communication, communicative language teaching approach contrasts sharply with traditional approaches and methods. Unfortunately, despite encouraging language teachers to implement communicative approach in their real practice, as Brown (2007) states, since there is not exact definition of CLT, it raises considerable confusion about what it means to teach communicatively. Similarly, Richards (2006) states that the language teachers who believe they follow CLT do not even have a consistent definition of this concept. Consequently, theories and practices of CLT face various discrepancies and mismatches (Takanashi, 2004). Taking teachers' beliefs into consideration, Karavas-Doukas (1996) maintains that teachers' beliefs can indirectly play a notable role in constructing their decision to implement methods and techniques of teaching. Furthermore, he states that one reason of the mismatch between the theory of certain methods and their actual practice is rooted in teachers' beliefs. There are many different definitions of the term 'belief' (Borg, 2006: 586) and researchers in this area need firstly to clarify what they exactly mean by this term. This study makes use of a working definition of 'belief' presented in the dictionary of applied linguistics, that is:

"Ideas and theories that teachers hold about themselves, teaching, language, learning and their students. Teachers' beliefs are thought to be stable constructs derived from their experience, observations, training 
and other sources and serve as a source of reference when teachers encounter new ideas, sometimes impeding the acceptance of new ideas or practices. Beliefs also serve as the source of teachers' classroom practices."

Widening this view, Kouritzin, Piquemal and Nakagawa (2007) declare that when teachers' beliefs are neglected in the process of designing new approaches to teaching, it is very probable that teachers do not embrace the new educational reform as they have not perceived it as a valuable teaching resource. Focusing on the context of Iran, where grammar-based approach has been the norm for many years, inspecting teachers' beliefs is seen as potentially beneficial for successful integration of CLT approach in language classes.

\section{Review of the Related Literature}

\subsection{Learning English in Iran}

As in other expanding circle countries where English has the status of a foreign language used for international communication (Kachru, 2005), English is greatly strengthening its place as the most dominant international communication language in Iran (Zare Behtash, Hashemi Toroujeni \& Safarzadeh Semnani, 2017). However, in spite of the fact that English is considered as an indubitable necessity for the country's growth in various areas, a number of studies have revealed that EFL instruction at state-run educational systems has been unsuccessful in providing learners with needed knowledge and skills for having a successful communication (Ostovar-Namaghi, 2006; Dahmardeh, 2009; Safari \& Rashidi, 2015). Although English is considered as one of the required courses for middle and high school levels and students at these levels take between two to four hours of English each week for about six years, it is not an exaggeration to claim that a student who graduates from a high school in Iran, unless those who take additional courses in English institutes, is hardly able to introduce himself or herself in English or to express or understand more than a few simple sentences (Dorshomal, Gorjian \& Pazhakh, 2013). Course textbooks at schools mainly focus on developing reading comprehension skill, vocabulary knowledge, and grammar with little emphasis on writing. Listening is almost absent in the syllabus, and speaking is limited to a few drills and short dialogues. In most of the private language institutes, the scenario seems to be completely different. To cope with this deficiency, in recent years, privately-operated language institutes have relied more on communicative approach of language teaching and instructional materials and hence are more responsive to learners' needs in order to compensate for the deficiency of formal EFL instruction in public schools (Gholami, Sarkhosh \& Abdi, 2016). 


\subsection{Characteristics and principles of CLT}

In contrast to traditional approaches in which teachers were considered as knowledge transmitters and learners were regarded as passive knowledge receivers, CLT is a learner-centered approach which insists on maintaining a social relationship between the learners and teachers. In learner-centered approaches, since learners have a sense of 'ownership', their motivation for learning increases (Brown, 2007) and they actually engage in an active negotiation between "the self, the learning process, and the object of learning” (Breen \& Candlin, 1980: 110).

Taking theoretical perspective into consideration, CLT has been conceptualized in two different ways, i.e., weak and strong versions, approximately in agreement with its two main sources: a communicative perspective on language and a communicative perspective on learning (Littlewood, 2014). The communicative perspective on language which is also called the weak version of CLT highlights the importance of providing learners with opportunities to use their English for communicative purposes, while the communicative perspective on learning, the 'strong' version of CLT, claims that language is acquired through communication without explicit instruction (Howatt, 1984).

In short, Brown (2007: 241) offers four interconnected characteristics as a definition of CLT:

- Classroom goals are focused on all of the components of communicative competence and not restricted to grammatical or linguistic competence.

- Language techniques are designed to engage learners in the pragmatic, authentic, functional use of language for meaningful purposes. Organizational language forms are not the central focus, but rather, aspects of language that enable the learner to accomplish those purposes.

- Fluency and accuracy are seen as complementary principles underlying communicative techniques. At times fluency may have to take on more importance that accuracy in order to keep learners meaningfully engaged in language use.

- In the communicative classroom, students ultimately have to use the language productively and receptively, in unrehearsed contexts.

\subsection{Teachers' beliefs and practices towards CLT}

While incorporating communicative language teaching approach in English language is not a new idea, teachers are still unsure about what CLT is and have different perceptions in comprehending and even in applying its principles in their classes. This mismatch between teachers' perceptions and practices shows that teachers' beliefs before applying any new approach should not be neglected (KaravasDoukas, 1996; Khatib \& Ashoori Tootkaboni, 2017). 
In an investigation to observe teacher's implementation of CLT, Nunan (1987) observed teachers in five classes and found out that in spite of performing communicative-based activities, presence of many traditional exercises were actually predominant and teachers were not really interested in the real tenets of communicative approach. Furthermore, he argued that:

"if one accepts a 'weak' interpretation of communicative language teaching, then $\mathrm{s} /$ he must accept the value of grammatical explanation, error correction, and drill" (Nunan, 1987: 141).

Tayjasanant and Barnard (2010) conducted a small-scale case study involving eight teachers from two schools in order to explore language teachers' beliefs and practices regarding the appropriateness of communicative methodology in Thailand. Data were collected through classroom observation and in-depth interviews with the participating teachers to discover what they believed about communicative English language teaching and the extent to which their classroom practices reflected their beliefs. The findings greatly confirmed empirical evidence derived from investigations in neighboring countries, that there is an extensive gap between the proposed aims and methodologies and what actually occurs in language classrooms.

In Japan, Nishino (2008) investigated 21 secondary school teachers' beliefs and practices concerning communicative language teaching in their classroom setting. The survey results showed that the participants in this study had solid knowledge of CLT with a relatively good understanding of teachers' and learners' roles in CLT classrooms. Meanwhile, their responses to applying CLT methodology in their classes revealed that for effective use of CLT, some changes in educational conditions such as more class hours and small class sizes were needed.

Chang (2011) conducted a research to explore Taiwanese college teachers' perceptions and experiences towards CLT and the reasons behind their beliefs. To this end, he employed face-to-face, semi-structured interviews. The results of the study showed that teachers held positive beliefs towards basic principles of CLT and emphasized the effectiveness of this approach. The factors that influenced the implementation of CLT were; the teachers, the students, and the educational system. Moreover, it was discovered that for successful implementation of CLT, not only teachers' professional training about CLT but also students' willingness and motivation to use English inside and outside the classroom have crucial roles.

Taking the context of Iran into consideration, Anani Sarab, Monfared and Safarzadeh (2016) investigated 75 Iranian school teachers' perception of CLT principles and practices through a combination of quantitative and qualitative methods of data collection. The obtained data using a semi-structured questionnaire and interviews with a smaller group of teachers revealed that a change in classroom 
arrangements is necessitated before CLT can be implemented effectively in secondary school English classes in Iran. Moreover, the results revealed that the employment of CLT procedures at the local level is at its beginning stages and might take time to take root.

Given the crucial role teachers' beliefs may play in adopting a certain curriculum and the widespread welcoming perception of teachers toward CLT throughout the world, the present study set forth to find out Iranian English language teachers beliefs at private English language institutes towards CLT principles regarding the fact that CLT-oriented curriculum has recently been introduced in the context of Iran and to the best of our knowledge, very few studies have tried to delve into this issue. To this aim, the present research tries to provide answers to the following research questions:

1. What is the overall belief of Iranian EFL teachers with respect to CLT principles?

2. To what extent are the CLT principles practiced by Iranian EFL teachers?

\section{Method}

\subsection{Participants}

The present study was carried out in two phases: using a questionnaire and classroom observation. Firstly, the questionnaire was administered to $154 \mathrm{EFL}$ teachers in private English language institutes in two provinces of Mazandaran $(34.4 \%)$ and Tehran $(65.6 \%)$ in Iran. In the second phase, from within the 154 participants, 20 teachers' classes from Mazandaran province were observed. Since the participants in both provinces had been selected from the institutes which followed the same ELT approach, i.e. CLT, and teachers were initially trained to teach English in the same way using the same teaching materials, hence, the participant who were available to the authors were selected to take part in observation phase of the study.

\subsection{Instruments}

\subsubsection{Questionnaire}

A questionnaire including six major tenets of CLT approach, namely, the role and contribution of the learners, the role of the teacher, the role of group/pair work, the place and importance of grammar, the role of the learners' native language and the quality and quantity of error correction and assessment was developed to serve as the instrument of the study. It consisted of 28 statements, including 21 favorable and 7 unfavorable items which followed the six-point Likert technique of scale construction. 


\subsubsection{Questionnaire development phase}

Since responses to the questionnaire constitute the data of this study, the following professional and academic acts were executed to have a reliable and valid questionnaire.

In order to determine the validity of the instrument, after reviewing the literature and generating 38 items, the items were submitted to a panel of experts who were professional members in the field of applied linguistics. The experts were asked to assess the questionnaire items in terms of the intelligibility, validity, content representativeness, ambiguity, bias and their appropriateness. They were requested to rate the items based on a four-point Likert-type scale. In the scale, 1 designated $\mathrm{Not}$ important to be included in the questionnaire', 2 was 'Somehow important to be included' 3 'Important to be included' and finally 4 meant 'Extremely important to be included in the questionnaire'. If the majority of the experts chose 'Important' or 'Extremely important to keep the item', that item was kept and if the majority demanded that the item to be omitted or found the item 'Not important' or 'Somehow important to be included', the item was deleted. The obtained results reduced the items from 38 to 30 items. Afterwards, in a pilot study, the questionnaire was distributed among 300 participants similar to the target population for whom the questionnaire was designed. The participants were asked to leave their comments on the questionnaires regarding layout, language, length, time it took to complete, clarity of questions, ease in following directions and any other comment about the research questionnaire. The comments were analyzed by the researcher, the necessary modifications were made and the questionnaire was refined accordingly.

\subsection{Questionnaire validation}

The main types of validity for the questionnaire validation investigated in the current study were face, content, and construct validity (Dörnyei, 2010).

I. Face and Content Validity: In order to have a questionnaire with an acceptable face validity, not only should a questionnaire be short, but it should also sound nice to the eyes (Dörnyei, 2010). To accomplish this aim, the face validity was met by employing a good lay out, font type and margin. Moreover, to estimate the content validity of the present questionnaire, the researcher requested a cadre of experts to review the draft and assess to what extent the items were in line with the purpose of the study.

II. Construct Validity: To statistically establish the construct validity of the CLT questionnaire, two types of factor analyses were run: exploratory and confirmatory factor analysis. 


\section{a. Exploratory Factor Analysis (EFA)}

According to Pallant (2007), two criteria must be met in order to determine the suitability of the data, that is, 'sample size' and the 'strength of association among the items'. Concerning the sample size, as Tabachnick and Fidell (2007) state, at least 300 cases or 5 to 10 cases for each item are needed. At this study, 300 participants responded to the questionnaire which helped to meet the criterion of 5-10 participants for each item.

The second criterion concerning the suitability of running factor analysis is related to the inter-correlations among the items in the questionnaire. Pallant (2007) suggests 0.3 coefficients is acceptable. If the correlation is below this level, factorability is not appropriate. Besides, KMO and Barlett's test were employed to test the factorability of the data. As a result, Barlett's test was found to be significant $(p=.00<.05)$ and KMO value was also calculated to be appropriate (.85) as it was above .60. After making sure about the factorability of data, factor analysis was run using SPSS V23 and the factors shown in Table 1 were determined ${ }^{1}$.

Table 1. Factor loading based on PCA.

\begin{tabular}{|c|c|c|c|c|c|c|}
\hline & 1 & 2 & 3 & 4 & 5 & 6 \\
\hline Q8 & .726 & & & & & \\
\hline Q7 & .704 & & & & & \\
\hline Q10 & .697 & & & & & \\
\hline Q9 & .654 & & & & & \\
\hline Q12 & .638 & & & & & \\
\hline Q11 & .623 & & & & & \\
\hline Q13 & .533 & & & & & \\
\hline Q1 & & .844 & & & & \\
\hline Q2 & & .733 & & & & \\
\hline Q3 & & .728 & & & & \\
\hline Q4 & & .706 & & & & \\
\hline Q5 & & .671 & & & & \\
\hline Q6 & & .448 & & & & \\
\hline Q14 & & & .779 & & & \\
\hline Q15 & & & .745 & & & \\
\hline Q16 & & & .739 & & & \\
\hline Q17 & & & .625 & & & \\
\hline Q18 & & & .560 & .733 & & \\
\hline Q27 & & & & .720 & & \\
\hline Q28 & & & & .664 & & \\
\hline Q30 & & & & .635 & & \\
\hline Q29 & & & & .302 & & \\
\hline Q19 & & & & & .612 & \\
\hline Q21 & & & & & .565 & \\
\hline Q20 & & & & & .539 & \\
\hline Q22 & & & & & .530 & \\
\hline Q23 & & & & & .476 & \\
\hline Q25 & & & & & & .789 \\
\hline Q24 & & & & & & .779 \\
\hline Q26 & & & & & & .562 \\
\hline
\end{tabular}

Extraction Method: PCA/ Rotation Method: Varimax with Kaiser Normalization/ Q: question 
In order to verify the relationship between observed variables, i.e. the questionnaire items and their underlying latent constructs, i.e. CLT tenets, CFA was run using LISREL software. Figure 1 provides the data of the CFA's first step².

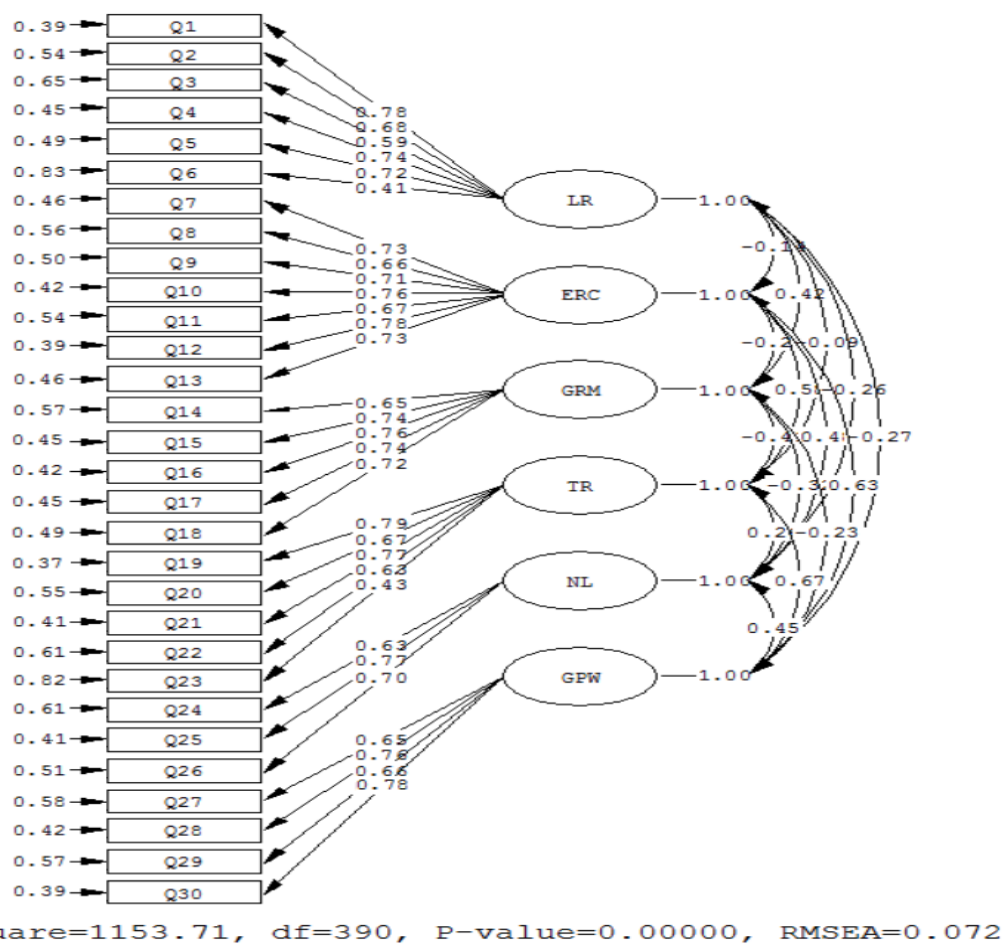

Figure 1. Measurement model of research variables in case of standardized solution.

Figure 1 displays factor loadings of each item in the questionnaire in connection with the intended factor. As stated by Straub (1989), the gain factor loadings should be more than 0.5 or ideally more than 0.7 . In the present study, 0.5 is regarded as the standard factor loading. Since the standard factor loading of 0.5 is acceptable, questions 6 and 23 with factor loadings less than 0.5 (Q6=0.41 \& Q23=0.43) were eliminated. Figure 2 also shows confirmatory factor analysis of the research variables after eliminating inappropriate items in the state of standardized solution. 


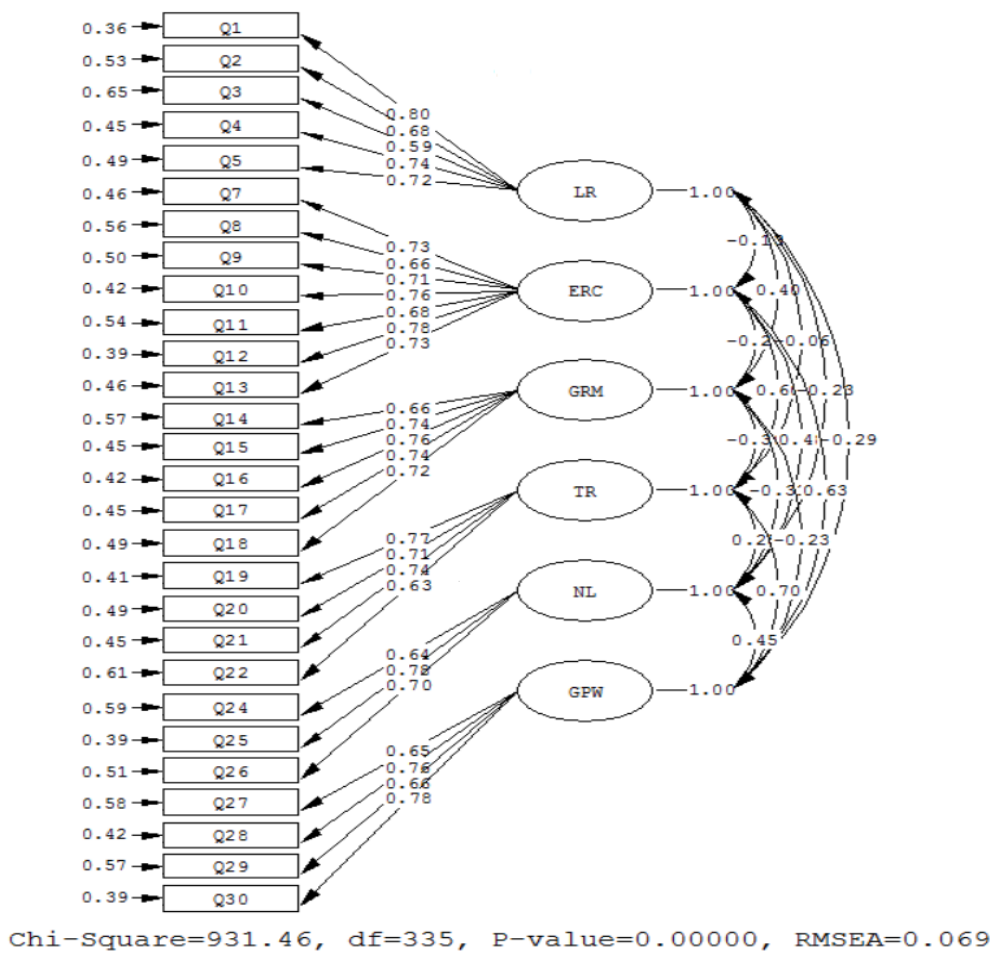

Figure 2. Measurement model of research variables in case of standardized solution (after removal of inappropriate items).

After eliminating 2 questions (Q6 \& Q23), the researchers came up with 28 items tapping the six major tenets of CLT.

\subsection{Reliability of the questionnaire}

For estimating the internal consistency of the questionnaire, Cronbach's Alpha coefficient was utilized. As stated by Dörnyei (2010), the reliability Index below 0.60 is regarded as weak, and above that is an acceptable measure for the reliability index of the questionnaire. In the present study, the results of the Cronbach's Alpha showed that the internal consistency of the whole questionnaire was 0.77 and for the six subscales in the questionnaire the reliability was estimated to be .81 (the role and contribution of the learners, 6 statements), 74 (the role of the teacher, 5 statements), .77 (the role of group/pair work, 4 statements), .78 (the place and importance of grammar, 5 statements), .72 (the role of learners' native language, 3 statements), and .82 (the quality and quantity of error correction and assessment, 7 statements).

\subsubsection{Classroom observation}

Since observation allows the study of a phenomenon in depth with many of the contextual variables present (Selinger \& Shohamy, 1989), it has always been regarded as one of the major data collection instruments in second and foreign language 
learning researches. To design an observation scheme, literature was reviewed and a number of developed observation schemes (Razmjoo \& Riazi, 2006) were studied. Accordingly, an observation checklist focusing on the six main tenant of CLT was designed. The content of the observation checklist is presented in Table 8 .

\subsection{Data collection and analysis}

To see what beliefs Iranian EFL teachers hold about CLT principles and the extent teachers practice them in EFL contexts, the data collected through questionnaire and classroom observation were analyzed using the following procedures.

The data collected through language teachers' questionnaire were subjected to descriptive statistics utilizing mean, frequency, percentage of each statement. The scale ranged from 6 to 1 , with 6 designating 'strongly agree' and 1 indicating 'strongly disagree'. The unfavorable items which were indicated by an asterisk $\left(^{*}\right)$ were recoded, so the positive end of the scale was 6 .

Regarding classroom observation, the main purpose was to ascertain whether or not teachers practice the principles of CLT in EFL classrooms while the actual lesson was going on. To this aim, 20 teacher participants' classes were observed by the researcher while they were teaching in their regular EFL classes. The researcher observed the English lessons in the complete observer role and put a tick mark on the checklist focusing on the main principles of communicative language teaching approach. Each observation session was scheduled for 90 minutes and the observation was conducted for twenty sessions all together. In other words, onesession observation was conducted for each teacher.

Finally, the data gathered by means of observation scheme were analyzed descriptively determining the amount of importance attached to each principle of CLT. The scale ranged from 5 to 1 , with 5 representing 'Very Much' and 1 representing 'Very Little'. To illustrate better the pattern of the different principles in observed domains, the first two alternatives (Very Much \& Much) and the last two (A Little \& Very Little) were combined.

\section{Results and discussion}

\subsection{Findings of the CLT questionnaire}

Questions 1 to 5 in Table 2 summarize teachers' beliefs towards the role and contribution of the learners in learning process. As it is clear, the majority of the respondents $(90.2 \%)$ agreed with the point that learners play a great role in the process of learning. Likewise, all the teachers agreed upon the issue that learners are expected to interact with each other either in the flesh, through pair and group work, or in their writing'. Focusing on item 3, more than half of the teachers (58.4\%) strongly agreed 
that 'learners need to have freedom to choose their language use rather than practicing what they are told to say'; whereas, only $2.6 \%$ of the teachers disagreed over that point. On the same fashion, in response to item 4, 1.9\% of the teachers to some extent disagreed with the statement that 'learner's own personal experience should be regarded as an important contributing element in language classrooms', while the rest of the teachers showed their favorable beliefs towards that. However, though in general teachers showed strong positive view towards the importance of the learners' role, a considerable portion of them (35\%) favored the idea that the learner is not in a position to suggest the content of the lesson (item 5).

Table 2. Teachers' beliefs on the role and contribution of the learners.

\begin{tabular}{|c|c|c|c|c|c|c|c|}
\hline Items & $\begin{array}{c}6 \\
1 * \\
f / p\end{array}$ & $\begin{array}{c}5 \\
2 * \\
f / p\end{array}$ & $\begin{array}{c}4 \\
3 * \\
f / p\end{array}$ & $\begin{array}{c}3 \\
4 * \\
\mathrm{f} / \mathrm{p}\end{array}$ & $\begin{array}{c}2 \\
5 * \\
\mathrm{f} / \mathrm{p}\end{array}$ & $\begin{array}{c}1 \\
6 * \\
f / p\end{array}$ & Mean \\
\hline $\begin{array}{l}\text { It is the learner who plays a great role in the } \\
\text { process of learning. }\end{array}$ & $\begin{array}{l}41 \\
26.6 \\
\end{array}$ & $\begin{array}{l}31 \\
20.1 \\
\end{array}$ & $\begin{array}{l}67 \\
43.5 \\
\end{array}$ & $\begin{array}{l}15 \\
9.7 \\
\end{array}$ & $\begin{array}{ll}0 \\
0.0 \\
\end{array}$ & $\begin{array}{l}0 \\
0.0 \\
\end{array}$ & 4.64 \\
\hline $\begin{array}{l}\text { Learners are expected to interact with each } \\
\text { other either in the flesh, through pair and } \\
\text { group work, or in their writing. }\end{array}$ & $\begin{array}{l}70 \\
45.5\end{array}$ & $\begin{array}{l}55 \\
35.7\end{array}$ & $\begin{array}{l}29 \\
18.8\end{array}$ & $\begin{array}{l}0 \\
0.0\end{array}$ & $\begin{array}{l}0 \\
0.0\end{array}$ & $\begin{array}{l}0 \\
0.0\end{array}$ & 5.27 \\
\hline $\begin{array}{l}\text { Learners need to have freedom to choose } \\
\text { their language use rather than practicing what } \\
\text { they are told to say. }\end{array}$ & $\begin{array}{l}90 \\
58.4\end{array}$ & $\begin{array}{l}48 \\
31.2\end{array}$ & $\begin{array}{l}12 \\
7.8\end{array}$ & $\begin{array}{l}4 \\
2.6\end{array}$ & $\begin{array}{l}0 \\
0.0\end{array}$ & $\begin{array}{l}0 \\
0.0\end{array}$ & 5.45 \\
\hline $\begin{array}{l}\text { Learner's own personal experience should be } \\
\text { regarded as an important contributing } \\
\text { element in language classrooms. }\end{array}$ & $\begin{array}{l}47 \\
30.5\end{array}$ & $\begin{array}{l}47 \\
30.5\end{array}$ & $\begin{array}{l}57 \\
37.0\end{array}$ & $\begin{array}{l}3 \\
1.9\end{array}$ & $\begin{array}{l}0 \\
0.0\end{array}$ & $\begin{array}{l}0 \\
0.0\end{array}$ & 4.90 \\
\hline $\begin{array}{l}5^{*} \text {. The learner is not in a position to suggest } \\
\text { what the content of the lesson should be or } \\
\text { what activities are useful for him/her. }\end{array}$ & $\begin{array}{l}9 \\
5.8\end{array}$ & $\begin{array}{l}8 \\
5.2\end{array}$ & $\begin{array}{l}37 \\
24.0\end{array}$ & $\begin{array}{l}57 \\
37.0\end{array}$ & $\begin{array}{l}31 \\
20.1\end{array}$ & $\begin{array}{l}12 \\
7.8\end{array}$ & 3.84 \\
\hline
\end{tabular}

To summarize, Table 2 implies that even though a small portion of the respondents revealed their misconception or weak perception about the role and contribution of the learners in communicative EFL classes, more than half of the respondents (with mean value of 4.82) indicated their strong positive beliefs and high level of understanding about the learners' role in foreign language classrooms. 
Table 3. Teachers' beliefs on error correction and assessment.

\begin{tabular}{|c|c|c|c|c|c|c|c|}
\hline Items & $\begin{array}{c}6 \\
1 * \\
f / p\end{array}$ & $\begin{array}{c}5 \\
2 * \\
f / p\end{array}$ & $\begin{array}{c}4 \\
3 * \\
\mathrm{f} / \mathrm{p}\end{array}$ & $\begin{array}{c}3 \\
4 * \\
\mathrm{f} / \mathrm{p}\end{array}$ & $\begin{array}{c}2 \\
5^{*} \\
\mathrm{f} / \mathrm{p}\end{array}$ & $\begin{array}{c}1 \\
6^{*} \\
\mathrm{f} / \mathrm{p}\end{array}$ & Mean \\
\hline $\begin{array}{l}6^{*} . \text { For evaluating learners' progress in } \\
\text { communication, their vocabulary and } \\
\text { structural knowledge should be assessed. }\end{array}$ & $\begin{array}{l}1 \\
.6\end{array}$ & $\begin{array}{l}3 \\
1.9\end{array}$ & $\begin{array}{l}6 \\
3.9\end{array}$ & $\begin{array}{l}45 \\
29.2\end{array}$ & $\begin{array}{l}58 \\
37.7\end{array}$ & $\begin{array}{l}41 \\
26.6\end{array}$ & 4.81 \\
\hline $\begin{array}{l}\text { 7. Errors are seen as a natural outcome of } \\
\text { the development of the communication skill } \\
\text { and are therefore tolerated. }\end{array}$ & $\begin{array}{l}95 \\
61.7\end{array}$ & $\begin{array}{l}46 \\
29.9\end{array}$ & $\begin{array}{l}13 \\
8.4\end{array}$ & $\begin{array}{l}0 \\
0.0\end{array}$ & $\begin{array}{ll}0 \\
0.0\end{array}$ & $\begin{array}{ll}0 \\
0.0\end{array}$ & 5.53 \\
\hline $\begin{array}{l}8^{*} \text {.Because of the learners' limited linguistic } \\
\text { knowledge, they should not be allowed to } \\
\text { correct each other's errors }\end{array}$ & $\begin{array}{ll}0 \\
0.0\end{array}$ & $\begin{array}{l}4 \\
2.6\end{array}$ & $\begin{array}{l}8 \\
5.2\end{array}$ & $\begin{array}{l}49 \\
31.8\end{array}$ & $\begin{array}{l}58 \\
37.7\end{array}$ & $\begin{array}{l}35 \\
22.7\end{array}$ & 4.73 \\
\hline $\begin{array}{l}\text { 9. It is better to evaluate learners' } \\
\text { performance in communicative based } \\
\text { activities such as role-plav. }\end{array}$ & $\begin{array}{l}21 \\
13.6\end{array}$ & $\begin{array}{l}45 \\
29.2\end{array}$ & $\begin{array}{l}59 \\
38.3\end{array}$ & $\begin{array}{l}25 \\
16.2\end{array}$ & $\begin{array}{l}4 \\
2.6\end{array}$ & $\begin{array}{ll}0 \\
0.0\end{array}$ & 4.35 \\
\hline $\begin{array}{l}\text { 10. Constant error correction is unnecessary } \\
\text { and even counter-productive. }\end{array}$ & $\begin{array}{l}42 \\
27.3\end{array}$ & $\begin{array}{l}49 \\
31.8\end{array}$ & $\begin{array}{l}50 \\
32.5\end{array}$ & $\begin{array}{l}13 \\
8.4\end{array}$ & $\begin{array}{l}0 \\
0.0\end{array}$ & $\begin{array}{l}0 \\
0.0\end{array}$ & 4.78 \\
\hline $\begin{array}{l}11 * \text {. Good evaluation is carried out when } \\
\text { the focus of evaluation is on accuracy. }\end{array}$ & $\begin{array}{l}26 \\
16.9\end{array}$ & $\begin{array}{l}28 \\
18.2\end{array}$ & $\begin{array}{l}38 \\
24.7\end{array}$ & $\begin{array}{l}25 \\
16.2\end{array}$ & $\begin{array}{l}22 \\
14.3\end{array}$ & $\begin{array}{l}15 \\
9.7\end{array}$ & 3.22 \\
\hline $\begin{array}{l}\text { 12. Correction from teachers should happen } \\
\text { only when there is a communication } \\
\text { breakdown. }\end{array}$ & $\begin{array}{l}17 \\
11.0\end{array}$ & $\begin{array}{l}35 \\
22.7\end{array}$ & $\begin{array}{l}43 \\
27.9\end{array}$ & $\begin{array}{l}32 \\
20.8\end{array}$ & $\begin{array}{l}23 \\
14.9\end{array}$ & $\begin{array}{l}4 \\
2.6\end{array}$ & 3.86 \\
\hline
\end{tabular}

For error correction and assessment group of items, three unfavorable (items 6, 8 and 11) and four favorable items were designed (items 7, 9, 10 and 12). The highest rate of agreement is seen for item 7 in which $61.7 \%$ of the teachers strongly agreed, $29.9 \%$ agreed, and $8.4 \%$ to some extent agreed with the statement that committing error is a natural phenomenon in learning process. This suggests that in line with Larsen-Freeman (2000) and Richards (2006), respondents favored the idea that as far as errors do not impede communication and comprehension, they should be treated as natural in the learning process. However, with regard to the teachers' perspective on the focus of evaluation, more than half of the teachers (59.8\%) agreed upon the point that 'good evaluation is carried out when the focus of evaluation is on accuracy', implying that a notable percentage of EFL teachers employ non- communicative or traditional ways of evaluation in the EFL context of Iran. 
Table 4. Teachers' beliefs on the role and importance of grammar.

\begin{tabular}{|c|c|c|c|c|c|c|c|}
\hline Items & $\begin{array}{c}6 \\
1 * \\
f / p\end{array}$ & $\begin{array}{c}5 \\
2 * \\
f / p\end{array}$ & $\begin{array}{c}4 \\
3 * \\
\mathrm{f} / \mathrm{p}\end{array}$ & $\begin{array}{c}3 \\
4 * \\
f / p\end{array}$ & $\begin{array}{c}2 \\
5^{*} \\
f / p\end{array}$ & $\begin{array}{c}1 \\
6 * \\
f / p\end{array}$ & Mean \\
\hline $\begin{array}{l}13^{*} \text {. Direct instruction of language rules } \\
\text { leads to effective communication. }\end{array}$ & $\begin{array}{l}12 \\
7.8\end{array}$ & $\begin{array}{l}18 \\
11.7\end{array}$ & $\begin{array}{l}30 \\
19.5\end{array}$ & $\begin{array}{l}37 \\
24.0\end{array}$ & $\begin{array}{l}35 \\
22.7\end{array}$ & $\begin{array}{l}22 \\
14.3\end{array}$ & 3.85 \\
\hline $\begin{array}{l}\text { 14. Less attention should be paid to the } \\
\text { overt presentation and discussion of } \\
\text { grammatical rules. }\end{array}$ & $\begin{array}{ll}36 \\
23.4\end{array}$ & $\begin{array}{l}37 \\
24.0\end{array}$ & $\begin{array}{l}39 \\
25.3\end{array}$ & $\begin{array}{l}22 \\
14.3\end{array}$ & $\begin{array}{l}11 \\
7.1\end{array}$ & $\begin{array}{l}9 \\
5.8\end{array}$ & 4.26 \\
\hline $\begin{array}{l}\text { 15. Language forms should be addressed } \\
\text { within a communicative context and not in } \\
\text { isolation. }\end{array}$ & $\begin{array}{l}18 \\
11.7\end{array}$ & $\begin{array}{l}36 \\
23.4\end{array}$ & $\begin{array}{l}53 \\
34.4\end{array}$ & $\begin{array}{l}34 \\
22.1\end{array}$ & $\begin{array}{l}6 \\
3.9\end{array}$ & $\begin{array}{l}7 \\
4.5\end{array}$ & 4.03 \\
\hline $\begin{array}{l}16^{*} \text {. The most important part of learning } \\
\text { English is practicing grammatical patterns. }\end{array}$ & $\begin{array}{l}0 \\
0.0\end{array}$ & $\begin{array}{l}0 \\
0.0\end{array}$ & $\begin{array}{l}0 \\
0.0\end{array}$ & $\begin{array}{l}20 \\
13.0\end{array}$ & $\begin{array}{l}53 \\
34.4\end{array}$ & $\begin{array}{l}81 \\
52.6\end{array}$ & 5.40 \\
\hline $\begin{array}{l}\text { 17. Learners seem to focus best on } \\
\text { grammar when it relates to their } \\
\text { communicative needs and experiences. }\end{array}$ & $\begin{array}{l}14 \\
9.1\end{array}$ & $\begin{array}{l}31 \\
20.1\end{array}$ & $\begin{array}{l}42 \\
27.3\end{array}$ & $\begin{array}{ll}36 \\
23.4\end{array}$ & $\begin{array}{l}22 \\
14.3\end{array}$ & $\begin{array}{l}9 \\
5.8\end{array}$ & 3.69 \\
\hline
\end{tabular}

Concerning the role and importance of grammar (Table 4), while 61\% of the participants indicated their agreement with item 13, i.e. 'direct instruction of language rules leads to effective communication', 39\% of the teachers expressed their disagreement to that point. Likewise, although two third $(72.7 \%)$ of the respondents showed their agreement to item 14, i.e., 'less attention should be paid to the overt presentation and discussion of grammatical rules', the rest $14.3 \%, 7.1 \%$, and $5.8 \%$ of them reported 'somewhat disagree', 'disagree', and 'strongly disagree' respectively. Table 4 also indicates that all the respondents with $52.6 \%$ strong disagreement, $34.4 \%$ disagreement and $13 \%$ average disagreement rejected the idea that practicing grammatical patterns is the most important part of learning English. In sum, by analyzing the results of items 13-17, one finds out that teachers' responses with mean value of 4.24 seems to indicate that Iranian EFL teachers have good perception of the role of grammar and its importance in language teaching.

Table 5. Teachers' beliefs on teacher' role.

\begin{tabular}{|c|c|c|c|c|c|c|c|}
\hline Items & $\begin{array}{c}6 \\
1 * \\
f / p\end{array}$ & $\begin{array}{c}5 \\
2 * \\
f / p\end{array}$ & $\begin{array}{c}4 \\
3 * \\
\mathrm{f} / \mathrm{p}\end{array}$ & $\begin{array}{c}3 \\
4 * \\
f / p\end{array}$ & $\begin{array}{c}2 \\
5 * \\
f / p\end{array}$ & $\begin{array}{c}1 \\
6 * \\
f / p\end{array}$ & Mean \\
\hline $\begin{array}{l}\text { 18. The teacher should set an environment } \\
\text { that is interactive and not excessive formal. }\end{array}$ & $\begin{array}{l}94 \\
61.0 \\
\end{array}$ & $\begin{array}{l}55 \\
35.7\end{array}$ & $\begin{array}{l}5 \\
3.2 \\
\end{array}$ & $\begin{array}{ll}0 \\
0.0\end{array}$ & $\begin{array}{ll}0 \\
0.0\end{array}$ & $\begin{array}{ll}0 \\
0.0\end{array}$ & 5.58 \\
\hline $\begin{array}{l}\text { 19. The teacher should facilitate } \\
\text { communication process and advise learners } \\
\text { during task performance. }\end{array}$ & $\begin{array}{l}71 \\
46.1\end{array}$ & $\begin{array}{ll}60 \\
39.0\end{array}$ & $\begin{array}{l}23 \\
14.9\end{array}$ & $\begin{array}{ll}0 \\
0.0\end{array}$ & $\begin{array}{ll}0 \\
0.0\end{array}$ & $\begin{array}{ll}0 \\
0.0\end{array}$ & 5.31 \\
\hline $\begin{array}{l}20^{*} \text {. The teacher's role is to act as 'authority' } \\
\text { in the language classroom }\end{array}$ & $\begin{array}{l}10 \\
6.5\end{array}$ & $\begin{array}{l}23 \\
14.9\end{array}$ & $\begin{array}{ll}36 \\
23.4\end{array}$ & $\begin{array}{l}43 \\
27.9\end{array}$ & $\begin{array}{l}29 \\
18.8\end{array}$ & $\begin{array}{l}13 \\
8.4\end{array}$ & 3.62 \\
\hline $\begin{array}{l}\text { 21. Teachers should help learners in any } \\
\text { way that motivates them to work with } \\
\text { language. }\end{array}$ & $\begin{array}{l}114 \\
74.0\end{array}$ & $\begin{array}{l}40 \\
26.0\end{array}$ & $\begin{array}{l}0 \\
0.0\end{array}$ & $\begin{array}{l}0 \\
0.0\end{array}$ & $\begin{array}{l}0 \\
0.0\end{array}$ & $\begin{array}{l}0 \\
0.0\end{array}$ & 5.74 \\
\hline
\end{tabular}


With regard to the role of the teachers in foreign language classes, Table 5 illustrates that more than half of the respondents $(61 \%)$ declared their strong agreement to the statement that teachers should provide an interactive and not an excessive formal environment in language classes. In addition, all the respondents (46.1\% 'strongly agree', 39\% 'agree', \& 14.9\% 'somewhat agree') unanimously agreed upon the point that the teacher should have a facilitator and advisor role in the classroom. As for item 20, a significant percentage of teachers (44.8\%) showed their tendency on favoring the traditional view of language teaching which puts the language teacher as authority and at the center of classroom. In total, teachers with an average mean value of 5.06 expressed their positive and strong belief on what role the teacher should play in EFL classes.

Table 6. Teachers' beliefs on the role of the learners' native language.

\begin{tabular}{|c|c|c|c|c|c|c|c|}
\hline Items & $\begin{array}{c}6 \\
1 * \\
\mathrm{f} / \mathrm{p}\end{array}$ & $\begin{array}{c}5 \\
2 * \\
\mathrm{f} / \mathrm{p}\end{array}$ & $\begin{array}{c}4 \\
3 * \\
\text { f/p }\end{array}$ & $\begin{array}{c}3 \\
4 * \\
\mathrm{f} / \mathrm{p}\end{array}$ & $\begin{array}{c}2 \\
5 * \\
\text { f/p }\end{array}$ & $\begin{array}{c}1 \\
6 * \\
f / p\end{array}$ & Mean \\
\hline $\begin{array}{l}\text { 22. Judicious use of learner's native } \\
\text { language is acceptable when feasible. }\end{array}$ & $\begin{array}{l}44 \\
28.6 \\
\end{array}$ & $\begin{array}{l}52 \\
33.8 \\
\end{array}$ & $\begin{array}{l}29 \\
18.8 \\
\end{array}$ & $\begin{array}{l}13 \\
8.4\end{array}$ & $\begin{array}{l}11 \\
7.1 \\
\end{array}$ & $\begin{array}{ll}5 \\
3.2 \\
\end{array}$ & 4.58 \\
\hline $\begin{array}{l}23^{*} \text {. Learners' native language should be a } \\
\text { vehicle for communication in language } \\
\text { classrooms. }\end{array}$ & $\begin{array}{l}0 \\
0.0\end{array}$ & $\begin{array}{ll}0 \\
0.0\end{array}$ & $\begin{array}{ll}0 \\
0.0\end{array}$ & $\begin{array}{l}0 \\
0.0\end{array}$ & $\begin{array}{l}49 \\
31.8\end{array}$ & $\begin{array}{l}105 \\
68.2\end{array}$ & 5.68 \\
\hline $\begin{array}{l}24^{*} \text {. Teachers must provide directions of } \\
\text { homework, class work and test directions } \\
\text { by using learners' native language. }\end{array}$ & $\begin{array}{l}11 \\
7.1\end{array}$ & $\begin{array}{l}15 \\
9.7\end{array}$ & $\begin{array}{l}28 \\
18.2\end{array}$ & $\begin{array}{l}29 \\
18.8\end{array}$ & $\begin{array}{ll}38 \\
24.7\end{array}$ & $\begin{array}{l}33 \\
21.4\end{array}$ & 4.08 \\
\hline
\end{tabular}

In response to items 22-24 in Table 6 which deal with teachers' beliefs towards the role of the learners' native language in EFL classes, $81.2 \%$ of the respondents expressed their agreement on the judicious use of learners' native language. On the other hand, while a large portion of the respondents $(64.9 \%)$ declared their disagreement with the issue that 'teachers must provide directions of homework, class work and test directions by using learners' native language', $18.2 \%, 9.7 \%$, and $7.1 \%$ of the respondents replied 'somewhat agree', 'agree', and 'strongly agree' respectively. Generally, the results imply that more than half of the participants with average mean value of 4.78 have strong positive perception about the role of the learners' native language in foreign language classrooms. 
Table 7. Teachers' beliefs on the role of group/pair work.

\begin{tabular}{|c|c|c|c|c|c|c|c|}
\hline Items & $\begin{array}{c}6 \\
1 * \\
f / p\end{array}$ & $\begin{array}{c}5 \\
2 * \\
\mathrm{f} / \mathrm{p}\end{array}$ & $\begin{array}{c}4 \\
3 * \\
\mathrm{f} / \mathrm{p}\end{array}$ & $\begin{array}{c}3 \\
4 * \\
f / p\end{array}$ & $\begin{array}{c}2 \\
5 * \\
\text { f/p }\end{array}$ & $\begin{array}{c}1 \\
6^{*} \\
\mathrm{f} / \mathrm{p}\end{array}$ & Mean \\
\hline $\begin{array}{l}\text { 25. Group/pair work activities can lead to } \\
\text { more developed ideas, and therefore greater } \\
\text { confidence and more effective } \\
\text { communication }\end{array}$ & $\begin{array}{l}64 \\
41.6\end{array}$ & $\begin{array}{l}52 \\
33.8\end{array}$ & $\begin{array}{l}28 \\
18.2\end{array}$ & $\begin{array}{l}10 \\
6.5\end{array}$ & $\begin{array}{l}0 \\
0.0\end{array}$ & $\begin{array}{l}0 \\
0.0\end{array}$ & 5.10 \\
\hline $\begin{array}{l}\text { 26. More emphasis should be given to active } \\
\text { and effective modes of learning such as pair } \\
\text { or group work. }\end{array}$ & $\begin{array}{l}48 \\
31.2\end{array}$ & $\begin{array}{ll}55 \\
35.7\end{array}$ & $\begin{array}{l}28 \\
18.2\end{array}$ & $\begin{array}{l}14 \\
9.1\end{array}$ & $\begin{array}{l}7 \\
4.5\end{array}$ & $\begin{array}{l}2 \\
1.3\end{array}$ & 4.76 \\
\hline $\begin{array}{l}27 * \text { Group/pair work tasks can never be } \\
\text { replace the whole class formal instruction. }\end{array}$ & $\begin{array}{l}13 \\
8.4 \\
\end{array}$ & $\begin{array}{ll}21 \\
13.6 \\
\end{array}$ & $\begin{array}{ll}23 \\
14.9 \\
\end{array}$ & $\begin{array}{ll}20 \\
13.0\end{array}$ & $\begin{array}{l}43 \\
27.9 \\
\end{array}$ & $\begin{array}{ll}34 \\
22.1 \\
\end{array}$ & 4.05 \\
\hline $\begin{array}{l}\text { 28. Group/pair work activities provide } \\
\text { knowledge and skills which lead to greater } \\
\text { success in undertaking tasks }\end{array}$ & $\begin{array}{l}49 \\
31.8\end{array}$ & $\begin{array}{l}61 \\
39.6\end{array}$ & $\begin{array}{l}33 \\
21.4\end{array}$ & $\begin{array}{l}11 \\
7.1\end{array}$ & $\begin{array}{ll}0 \\
0.0\end{array}$ & $\begin{array}{ll}0 \\
0.0\end{array}$ & 4.96 \\
\hline
\end{tabular}

For the group of items dealing with teachers' beliefs on the role of group/pair work (Table 7), the results provide evidence that a considerable portion of the respondents with mean value of 4.49 appreciate and have high perception of the importance of incorporating group and pair work tasks in language classes. For instance, $93.6 \%$ of the respondents manifested their agreement with the issue that group/pair work activities lead to more effective communication. In a similar manner, in response to item $26,31.2 \%, 35.7 \%$, and $18.2 \%$ of the respondents revealed their strong agreement, agreement, and average agreement respectively with giving more emphasis to active modes of learning such as group and pair work. Likewise, a large percentage of the respondents $(63 \%)$ indicated their disagreement on the point that 'Group/pair work tasks can never be replaced the whole class formal instruction'.

\subsection{Findings of the classroom observations}

Similar to the questionnaire survey used in this study, the statements used in the observation checklist were categorized into two domains; favorable and unfavorable items (items 1, 2, 4, 11, 12, 14, 16, 17 and 19 which were shown by an asterisk). Table 8 below presents the amount of importance attached to the features of CLT in the classes observed. 
Table 8. Descriptive statistics of classroom observation (Frequency \& Percentage).

\begin{tabular}{|c|c|c|c|c|c|c|}
\hline \multirow{2}{*}{ Items } & \multicolumn{2}{|c|}{$\mathbf{V M}+\mathbf{M}$} & \multicolumn{2}{|c|}{ A } & \multicolumn{2}{|c|}{$\mathbf{A L}+\mathbf{L}$} \\
\hline & $\mathrm{f}$ & $\%$ & f & $\%$ & $\mathrm{f}$ & $\%$ \\
\hline \multicolumn{7}{|l|}{ Grammar Role } \\
\hline $\begin{array}{l}1 * \text { The formal properties of language are treated in } \\
\text { isolation from use. }\end{array}$ & 15 & 75 & 4 & 20 & 1 & 5 \\
\hline 2*. Grammar is taught systematically. & 13 & 65 & 4 & 20 & 3 & 15 \\
\hline $\begin{array}{l}\text { 3. Introduce the new language items in context and } \\
\text { demonstrate the use and meaning of the new language. }\end{array}$ & 2 & 10 & 4 & 20 & 14 & 70 \\
\hline \multicolumn{7}{|l|}{ Teacher's Role } \\
\hline 4*. Act as authority & 15 & 75 & 4 & 20 & 1 & 5 \\
\hline 5. Facilitate English language communication & 5 & 25 & 3 & 15 & 12 & 60 \\
\hline $\begin{array}{l}\text { 6. Involve learners in role play, simulation or any kind } \\
\text { of drama }\end{array}$ & 5 & 25 & 4 & 20 & 11 & 55 \\
\hline \multicolumn{7}{|l|}{ Learner's role } \\
\hline 7. More student-centered environment & 5 & 25 & 6 & 30 & 9 & 45 \\
\hline $\begin{array}{l}\text { 8. Learners are actively engaged in negotiating meaning } \\
\text { and try to make themselves understood }\end{array}$ & 5 & 25 & 5 & 25 & 10 & 50 \\
\hline $\begin{array}{l}\text { 9. Learners participate in proposing English language } \\
\text { activities and lesson materials. }\end{array}$ & 0 & 0 & 0 & 0 & 20 & 100 \\
\hline \multicolumn{7}{|l|}{ Group/Pair Work } \\
\hline 10. More emphasis on group/pair work tasks & 9 & 45 & 7 & 35 & 4 & 20 \\
\hline $11 *$. Use individual -seat work & 6 & 30 & 4 & 20 & 10 & 50 \\
\hline 12*. Works with the whole class & 5 & 25 & 4 & 20 & 11 & 55 \\
\hline \multicolumn{7}{|l|}{ Native Language Role } \\
\hline $\begin{array}{l}\text { 13.Use of target language as a medium of } \\
\text { communication }\end{array}$ & 16 & 80 & 4 & 20 & 0 & 0 \\
\hline $\begin{array}{l}\text { 14*. Directions for exercises and activities are given in } \\
\text { native language }\end{array}$ & 2 & 10 & 3 & 15 & 15 & 75 \\
\hline \multicolumn{7}{|l|}{ Error Correction \& Evaluation } \\
\hline 15. Students give each other feedback & 3 & 15 & 5 & 25 & 12 & 60 \\
\hline $16^{*}$. Address errors by providing explanation & 9 & 45 & 7 & 35 & 4 & 20 \\
\hline $\begin{array}{l}17 * \text {. Correct students directly and on the spot } \\
\text { whenever they make a mistake }\end{array}$ & 9 & 45 & 7 & 35 & 4 & 20 \\
\hline 18. Tolerate errors & 2 & 10 & 6 & 30 & 12 & 60 \\
\hline $\begin{array}{l}\text { 19*. Evaluate students' performance on the basis of } \\
\text { their accuracy }\end{array}$ & 15 & 75 & 4 & 20 & 1 & 5 \\
\hline
\end{tabular}

As illustrated in Table 8, participating teachers attached the least amount of importance to the most representative tenets of CLT in their real practice. To be more specific, a close examination of observation checklist results reveals that the majority of the teachers taught formal aspects of language isolated from its use $(75 \%, 20 \%$, and $5 \%$ of the teachers taught grammatical rules in isolation 'VM+M', 'A' and 'AL+L' respectively) and while $15 \%$ of the participants practiced grammar 'A Little' and 'Little' systematically, the rest $65 \%$ and $20 \%$ of them taught grammar very much/much and averagely respectively in a systematic mode. The results of the third item also confirmed the issue that in real practice, the teachers did not present new language items in a meaningful context and while $10 \%$ of the observed teachers acted in line with CLT principle, the rest of them drew learners' attention to formal aspects 
of language in an explicit or deductive way. On the same fashion, in terms of teachers' role, the results depict that $75 \%$ of the participants acted mainly as an authority and only $5 \%$ of the teachers were evaluated 'A Little' and 'Little' in this regard. Similarly, teachers' evaluation in terms of their facilitative role in EFL classes revealed that while $25 \%$ and $20 \%$ of the teachers took facilitative role ' $\mathrm{VM}+\mathrm{M}$ ' and 'A' respectively, a considerable portion of them (55\%) took more the role of knowledge imparter rather than a facilitator of learning process. By the same token, classes were mainly teachercentered and in 50\% of the observed classes, learners were a little and little engaged in negotiating meaning. Moreover, in none of the classes learners were asked to participate in proposing activities and lesson materials. The obtained results were evaluated as totally unfavorable, reflecting the extent teachers preferred to dictate classroom activities and materials and ignore learners and their roles in suggesting needed materials.

Respecting the extent that group and pair work activities were emphasized, the results showed that teachers mainly gave more importance to group and pair work tasks $(45 \%)$ compared to individual-seat work $(30 \%)$ or whole-work activities $(25 \%)$. On that account, one can conclude that in terms of incorporating group/pair work activities in EFL context of Iran, CLT is moderately welcomed in teachers' real practice. Likewise, focusing on the role of the learners' native language, analyzing item 13 reveals that a large proportion of the participants $(80 \%)$ manipulated target language extensively as a medium of communication. Accordingly, when it comes to the role of the learners' native language in EFL classes, classroom observation results provide evidence that participants mostly adhered to CLT principle by using target language as a medium of communication. Similarly, teachers' evaluation in terms of item 14 shows that while $10 \%$ and $15 \%$ of the observed teachers gave required directions for doing exercises and activities in learners' native language very much/much and averagely respectively, the rest of them $(75 \%)$ provided the needed information in target language. In general, the extent teachers utilized target language in real class conditions supported their beliefs regarding the role of the students' native language mentioned earlier in questionnaire analysis section.

Inspecting teachers' real practice in terms of the way they deal with learners' errors and their evaluation criterion also showed that in line with Tayjasanant and Barnard's (2010) study, there was a heavy focus in most of the classes on making the students understand grammatical forms, and to apply them correctly. To be exact, $45 \%$ and $35 \%$ of the teachers addressed students' mistakes by providing extensive and average explanation respectively (item 16). Similarly, while $45 \%$ of the teachers corrected learners directly and on the spot (item 17), only $10 \%$ of them were patient enough in dealing with learners' mistakes. In addition, based on the results of item 19, teachers' evaluation criterion was to a great extent $(75 \%)$ based on learners' accuracy rather than fluency. 
Taking everything into consideration, in spite of the teachers' high degree of perception of CLT principals, their real practices were less compatible with their beliefs. Tables 9 and 10 present a clearer picture of the differences existing in teachers' beliefs and their practice respecting the six major principles of CLT.

Table 9. Summary of weighing of teachers' beliefs regarding CLT principles.

\begin{tabular}{|l|c|c|c|c|}
\hline \multicolumn{1}{|c|}{ Principles } & W & F & RF & UF \\
& & $\mathbf{4 . 3 4 - 6}$ & $\mathbf{2 . 6 7 - 4 . 3 3}$ & $\mathbf{1 - 2 . 6 6}$ \\
\hline Grammar Role & 4.24 & & $\sqrt{ }$ & \\
\hline Teacher's Role & 5.06 & $\sqrt{ }$ & & \\
\hline Learner's Role & 4.82 & $\sqrt{ }$ & & \\
\hline Group/pair Work & 4.49 & $\sqrt{ }$ & & \\
\hline Native Language Role & 4.78 & $\sqrt{ }$ & & \\
\hline Error correction and Evaluation & 4.46 & $\sqrt{ }$ & & \\
\hline Total & 4.68 & $\sqrt{ }$ & & \\
\hline
\end{tabular}

As Table 9 illustrates, except the role of grammar which is considered as rather favorable, the other principles are regarded as favorable in the analysis of teachers' beliefs towards main principles of CLT. Generally, in line with literature (Razmjoo \& Riazi, 2006; Chang, 2011; Wong, 2012; Rajabi \& Godazhdar Mombeiny, 2016) teachers' beliefs were highly in accordance with CLT principles. However, as shown in Table 10, the results of classroom observation demonstrated that classroom practices are not necessarily a reflection of teachers' beliefs.

Table 1o. Summary of weighing of teachers' observation regarding CLT principles.

\begin{tabular}{|l|c|c|c|c|}
\hline \multicolumn{1}{|c|}{ Principles } & W & F & RF & UF \\
& & $\mathbf{3 . 6 7 - 5}$ & $\mathbf{2 . 3 4 - 3 . 6 6}$ & $\mathbf{1 - 2 . 3 3}$ \\
\hline Grammar Role & 2.05 & & & $\sqrt{ }$ \\
\hline Teacher's Role & 2.30 & & & $\sqrt{ }$ \\
\hline Learner's Role & 2.10 & & & $\sqrt{ }$ \\
\hline Group/pair Work & 3.40 & & $\sqrt{ }$ & \\
\hline Native Language Role & 4.12 & $\sqrt{ }$ & & \\
\hline Error correction and Evaluation & 2.32 & & & $\sqrt{ }$ \\
\hline Total & 2.71 & & $\sqrt{ }$ & \\
\hline
\end{tabular}

As it is shown in Table 10, except for the role of learners' native language which was evaluated as favorable, the other principles were considered as either rather favorable (role of group/pair work) or unfavorable (grammar role, teacher's role, learner's role, and error correction and evaluation). Comparing teachers' beliefs with their real practice of CLT, as Tables 9 and 10 illustrate, the only principle toward which teachers' beliefs and practices were in common was related to the role of the learners' native language in EFL teaching settings. Taking the other principles into consideration, while teachers reported their rather favorable beliefs toward the role and importance of teaching grammar, results of the observation checklist analysis 
showed that the participating teachers were mostly inclined toward traditional methods of teaching grammar. Moreover, the three principles of teachers' role, learners' role and error correction and evaluation were evaluated as favorable according to teachers' responses to the questionnaire items. However, the observation results yielded unfavorable results which were to a great extent in contrast with CLT guidelines. Finally, in terms of the role of group and pair work tasks in language classrooms, while according to the survey results, most of the participating teachers' appreciated and had high perception of the importance of incorporating group and pair work tasks in language classes, observation checklist analysis results indicated that in reality, about half of the teachers implement these types of activities in their real practice. In sum, the general emerging picture was that in spite of the teachers' high degree of perception of CLT principals, they were less successful in their efforts to stick to its spirit. There are numerous reasons that can explain this result.

The paradoxical disparities that exist between what teachers believe and profess and what they actually practice in the EFL classroom is noted by many scholars. Among them, scholars such as Savignon (2002) and Gatbonton and Segalowitz (2005) seem to share similar perceptions, and highlighting the fact that there seems to be weak relationship between what teachers state and their accrual classroom practices (specially referring to CLT). Similarly, our findings echo Karavas- Doukas' concerns (1996: 187):

"Despite the widespread adoption of communicative approach by textbooks and curricula around the world, research suggests that CLT principles in classrooms are rare, with most teachers professing commitment to the communicative approach but following more structural approach in classrooms".

These results also echo those from previous studies conducted in the EFL context of Iran (Mowlaie \& Rahimi, 2010; Anani Sarab et al., 2016) and other EFL/ESL contexts (Nishino, 2008; Tayjasanant \& Barnard's, 2010). That is, in agreement with previous studies, comparing teachers' beliefs and practices revealed that teachers' classroom practices are not necessarily a reflection of teachers' beliefs about teaching and learning and there is a wide gap between the aims and approaches advocated by the official agents and what actually happens in language classrooms.

Despite the universal consensus on the CLT rationale, successful integration of CLT to EFL contexts, especially in the context of Iran, has proven problematic owing to certain limitations (Maftoon, 2002; Dorshomal et al., 2013). As Maftoon (2002) postulates, to make an educational approach appropriate for a specific context, it should be sensitive to the cultural and pedagogical systems of that context, as well as the needs of those who receive training under that very approach. By taking a close look to the advent of CLT, we find out that CLT was firstly designed to meet the communicative needs of the language learners in the second language milieu. Since 
there is a huge difference between EFL and ESL contexts, one cannot ignore the fact that they require two totally different pedagogical practices. Consequently, application of CLT in foreign contexts will probably do more harm than good to the educational standards of the recipient (Maftoon, 2002).

The other militating factor against the effective implementation of CLT in Iran may be due to the nature of examinations at either the national or institutional level. In most cases, including the university entrance exam and graduation examinations, learners' linguistic knowledge rather than their communicative competence is assessed. Suffering from negative washback of the traditional examination system, English classrooms in Iran tend to be more grammar-oriented than communicative in practice. Radical changing in the current exam system of Iran seems to be an urgent need and should receive extreme attention by the change agents. Nonetheless, as it is not clear how and when it will be reformed, the negative washback will continue and this can spoil the attempts of teachers who are determined to stand by the change.

Last but not least, some practical constraints may also account for unsuccessful implementation of CLT in EFL context of Iran, such as large class size, teachers' low language proficiency, and lack of congruence between educational policies and realities of the teaching context.

\section{CONCLUSION}

The present study intended to contribute to the current CLT literature through investigating English language teachers' beliefs in the private institutes of Iran toward communicative language teaching approach and the extent they realize CLT in their real practice. The results of this study lend support to Savignon's (2002) claim that theory and practice are often at odds. As the overall findings of the study indicated there is a huge discrepancy between teachers' classroom practice and their expressed beliefs.

However, as discussed above, the identification of mismatch between teachers' classroom practice and their beliefs is not unique to this study. More often than not, this is due to neglecting teachers' existing beliefs prior to the establishment of a new approach (Karavas-Doukas, 1996). Teacher training courses focus on transforming information about the new approach and persuading teachers of its effectiveness. However, when the teachers come back to their classrooms they misapprehend the new ideas and interpret them inappropriately to adjust to their existing classroom routines. While, believing that they are performing exactly what the new approach calls for.

Owing to the fact that the role of English in Iran is continuing to grow and the idea of communicative language teaching has become and will likely continue to be 
popular among teachers, teachers' beliefs as a starting point in any teacher training courses should be taken into consideration by teacher educators and as Gorsuch (2001) suggests, the best way to understand the most effective ways of applying CLT is conducting more research to understand teachers' and learners' beliefs and perceptions toward it.

In conclusion, it is noteworthy to mention that since the participants of the current study were selected among those teaching in private language institutes, extreme caution should be taken in generalizing the results to broader population of teachers in Iran or other EFL settings.

\section{REFERENCES}

Anani Sarab, M. R., Monfared, A. \& Safarzadeh, M. M. (2016). Secondary EFL school teachers' perceptions of CLT principles and practices: An exploratory survey. Iranian Journal of Language Teaching Research, 4(3), 109-130.

Borg, S. (2006). Teacher cognition and language education: Research and practice. London: Continuum.

Breen, M. P. \& Candlin, C. (1980). The essentials of a communicative curriculum in language teaching. Applied Linguistics, 1(2), 89-112.

Brown, H. D. (2007). Teaching by principles: An interactive approach to language pedagogy (3 ${ }^{\text {rd }}$ ed.). New York: Pearson ESL.

Chang, M. (2011). Factors affecting the implementation of communicative language teaching in Taiwanese college English classes. ELT Journal, 4(2), 3-12.

Dahmardeh, M. (2009). Communicative textbooks: English language textbooks Iranian secondary school. Linguistik Online, 40(4), 45-61.

Dörnyei, Z. (2010). Questionnaires in second language research: Construction, administration, and processing. New York, NY: Routledge.

Dorshomal, N., Gorjian, B. \& Pazhakh, A. (2013). The role of pedagogical films in developing pre-intermediate Iranian EFL learners' speaking skill: The case of motivation. International Journal of Language Learning and Applied Linguistics World, 4(4), 254- 268.

Gatbonton, E. \& Segalowitz, N. (2005). Rethinking communicative language teaching: A focus on access to fluency. Canadian Modern Language Review, 61, 325-353.

Gholami, J., Sarkhosh, M. \& Abdi, H. (2016). An exploration of teaching practices of private, public, and public-private EFL teachers in Iran. Journal of Teacher Education for Sustainability, 18(1), 16-33. 
Gorsuch, G. (2001). Japanese EFL teachers' perceptions of communicative, audiolingual and yakudoku activities: The plan versus the reality. Education Policy Analysis Archives, 9(10), 11-15.

Howatt, A. P. R. (1984). A history of English language teaching. Oxford: Oxford University Press.

Hymes, D. H. (1972). On communicative competence. In J. B. Pride \& J. Holmes (Eds.), Sociolinguistics (pp. 269-293). Baltimore, USA: Penguin Education, Penguin Books Ltd.

Kachru, B. B. (2005). Asian Englishes: Beyond the canon. Hong Kong: Hong Kong University Press.

Karavas-Doukas, E. (1996). Using attitude scales to investigate teachers' attitude to the communicative approach. ELT Journal, 50(3), 187-198.

Khatib, M. \& Ashoori Tootaboni, A. (2017). Exploring EFL learners' beliefs toward communicative language teaching: A case study of Iranian EFL learners. Journal of English Language Teaching and Learning, 9(20), 109-134.

Kouritzin, S. G., Piquemal, N. A. C. \& Nakagawa, S. (2007). Pre-service teachers' belief about foreign language teaching and learning. Journal of Multilingual and Multicultural Development, 28(3), 220-237.

Larsen-Freeman, D. (2000). Techniques and principles in language teaching. Oxford: Oxford University Press.

Littlewood, W. (2014). Communication-oriented language teaching: Where are we now? Where do we go from here? Language Teaching, 47(3), 349-362.

Maftoon, P. (2002). Universal relevance of communicative language teaching: Some reservations. The International Journal of Humanities, 9(2), 49-54.

Mowlaie, B. \& Rahimi, A. (2010). The effect of teachers' attitude about communicative language teaching on their practice: Do they practice what they preach? Procedia - Social and Behavioral Sciences, 9, 1524-1528.

Nishino, T. (2008). Japanese secondary school teachers' beliefs and practices regarding communicative language teaching: An exploratory survey. JALT Journal, 30(1), 27-51.

Nunan, D. (1987). Communicative language teaching: Making it work. ELT Journal, 41(2), 136-145.

Ostovar-Namaghi, S. A. (2006). Language teachers' evaluation of curriculum change: A qualitative study. The Qualitative Report, 22(2), 391-409. 
Pallant, J. (2007). SPSS survival manual: A step by step guide to data analysis using SPSS for windows. England: McGraw Hill Open University Press.

Rajabi, P. \& Godazhdar Mombeiny, G. A. (2016). Iranian EFL teachers' attitudes towards communicative language teaching. Modern Journal of Language Teaching Methods, 6(1), 536-550.

Razmjoo, S. A. \& Riazi, A. (2006). Do high schools or private institutes practice communicative language teaching? A case study of Shiraz teachers' in high schools and institutes. The Reading Matrix, 6(3), 363.

Richards, J. C. (2006). Communicative language teaching today. Cambridge: Cambridge University Press.

Safari, P. \& Rashidi, N. (2015). Teacher education beyond transmission: Challenges and opportunities for Iranian teachers of English. Issues in Educational Research, 25(2), 187- 202 .

Savignon, S. J. (2002). Interpreting Communicative Language Teaching. New Heaven: Yale University Press.

Selinger, H. \& Shohamy, E. (1989). Second language research methods. Oxford: Oxford University Press.

Straub, D. W. (1989). Validating instruments in MIS research. MIS Quarterly, 13(2), 147-169.

Tabachnick, B. G. \& Fidell, L. S. (2007). Using multivariate statistics. Boston: Allyn and Bacon.

Takanashi, Y. (2004). TEFL and communication styles in Japanese culture. Language, Culture and Curriculum, 17(1), 1-14.

Tayjasanant, C. \& Barnard, R. (2010). Language teachers' beliefs and practices regarding the appropriateness of communicative methodology: A case study from Thailand. The Journal of Asia TEFL, 7(2), 279-311.

Wong, C. (2012). A case study of college level second language teachers' perceptions and implementations of communicative language teaching. Professional Educator, 36(2), 18-34.

Zare Behtash, E., Hashemi Toroujeni, S. M. \& Safarzade Samani, F. (2017). An introduction to the medieval English: The historical and literary context, traces of church and philosophical movements in the literature. Advances in Language and Literary Studies, 8(1), 143-151. 


\section{NOTES}

${ }^{1}$ Related to Table 1. Component 1: Learner's role, Component 2: Error Correction and Evaluation, Component 3: The role of grammar, Component 4: Teacher's role, Component 5: The role of Native Language, Component 6: The Role of Group/Pair Work

${ }^{2}$ Related to Figure 1. LR: Learner's Role; ERC: Error Correction and Evaluation; GRM: Role of Grammar; TR: Teacher's Role; NL: Role of the Native Language; GPW: The Role of Group/Pair Work 